\title{
Lupane Triterpenoids and New Derivatives as Antiproliferative Agents Against Prostate Cancer Cells
}

\author{
MARÍA JULIA CASTRO ${ }^{1}$, VALERIA PILAR CAREAGA ${ }^{2,3}$, PAULA ALEJANDRA SACCA ${ }^{3}$, \\ MARÍA BELÉN FARAONI ${ }^{1,4}$, ANA PAULA MURRAY ${ }^{1}$ and JUAN CARLOS CALVO ${ }^{3}$ \\ ${ }^{1}$ Institute of Chemistry of the South (INQUISUR), CONICET, Department of Chemistry, \\ National University of the South, Bahía Blanca, Argentina; \\ ${ }^{2}$ Microanalysis Unit and Physical Methods in Organic Chemistry (UMYMFOR), UBA-CONICET, \\ Department of Organic Chemistry, School of Exact and Natural Sciences, \\ University of Buenos Aires, Buenos Aires, Argentina; \\ ${ }^{3}$ Institute of Biology and Experimental Medicine (IBYME), CONICET, Department of Biological Chemistry, \\ School of Exact and Natural Sciences, University of Buenos Aires, Buenos Aires, Argentina; \\ ${ }^{4}$ Research Member of Commission of Scientific Research (CIC), Buenos Aires, Argentina
}

\begin{abstract}
Background/Aim: This study examined the potential role of natural triterpenoids lupeol, calenduladiol and heliantriol B2, and a set of 19 derivatives, as antiproliferative and antimetastatic agents against prostate cancer cells. Materials and Methods: Natural triterpenoids were isolated from Chuqiraga erinaceae. Analogs were obtained by transformations of lupeol and calenduladiol. The effects of compounds on PC-3 and LNCaP cells were determined using the MTT assay. Compounds with halfmaximal inhibitory concentration $<70 \mu M$ were evaluated as antimetastatic agents by a wound-healing assay. Results: Lupeol-3 $\beta$-sulfate, a new semisynthetic lupane, was the most active compound. In general, sulfated derivatives displayed higher activity than the lead against both cell lines. A new analog, calenduladiol-3 $\beta$-monosulfate, inhibited the migration of PC-3 cells; heliantriol B2 and 3 $\beta$-aminolupane inhibited the migration of LNCaP cells in a concentration-dependent manner. Conclusion: Our study provides novel agents with cytotoxic effects on prostate cancer cells, which may represent a potential new therapeutic approach for prostate cancer.
\end{abstract}

Prostate cancer $(\mathrm{PCa})$ is the most common malignancy in elderly men in developed countries, aside from skin cancer, and is one of the top-five types of cancer killing men worldwide (1). Although incidence rates have decreased in

Correspondence to: María Julia Castro, Institute of Chemistry of the South (INQUISUR), CONICET, Department of Chemistry, National University of the South, Alem 1253, B8000CPB, Bahía Blanca, Argentina. E-mail: julia.castro@uns.edu.ar

Key Words: Triterpenoids, semisynthesis, lupane derivatives, prostate cancer.
Western countries, increased incidence and mortality rates have been observed in several Asian countries in recent years. While there are several factors associated with PCa risk, no preventable risk factors have yet been identified for this disease (2). In general, treatment of early-stage PCa is effective and involves radiotherapy, radical prostatectomy, cryosurgery, or hormonal therapy. However, when the disease is diagnosed at an advanced stage, the current treatment options have limited efficacy and cause undesirable sideeffects, leading to disease progression and metastasis. Therefore, the development of novel therapeutic modalities and preventive approaches are important in improving the survival and quality of life of patients with PCa.

Historically, nature has served as a source of medicinal products used in the treatment of many diseases, including cancer. Nowadays, naturally-occurring products continue to play a relevant role in cancer therapy with a substantial number of anticancer agents used in the clinic that are natural or derived from natural products (3).

Triterpenoids are the ubiquitous secondary metabolites that can be also found in the human diet, largely derived from cereals, fruits, vegetables and plant-derived oils. They have been widely studied due to their broad spectrum of biological activities (4). In particular, pentacyclic triterpene alcohols isolated from plants of the Asteraceae family have been shown to exhibit cytotoxic activity against human cancer cell lines (5-7). Among them, lupeol (1) [1up-20(29)en-3 $\beta$-ol], has been shown to display moderate potential in cancer treatment through inhibition of multiple intracellular signaling molecules and transcription factors involved in the initiation, progression, and promotion of tumors (8). Several lupeol derivatives have also been synthesized to improve cytotoxicity against different human cancer cell lines (9-11). During the past few decades, the in vitro and in vivo 
anticancer efficacy of lupeol against human PCa cells without cytotoxicity to non neoplastic prostate epithelial cell has been reported (12-15). Moreover, lupeol has been shown to exhibit great promise as chemopreventive agent and is considered an essential dietary agent for the prevention of PCa that could be used alone or in combination with traditional chemotherapeutic agents to prevent the occurrence of cancer, metastatic spread, or even to treat cancer $(16,17)$.

Chuquiraga erinacea subsp. erinacea (Asteraceae) is an endemic species widely distributed in Argentina. Its leaves are consumed locally in infusion or decoction to relieve stomach, hepatic and kidney diseases, and to strength brain and nerves (18). The phytochemical analysis of this species led to the isolation of several lupane triterpenoids, including lupeol (1), calenduladiol (2), and heliantriol B2 (3) (Figure 1). Both $\mathbf{1}$ and $\mathbf{2}$ were found in significant quantities $(0.19 \%$ and $0.15 \%$, respectively) in the ethanolic extract of the aerial parts of $C$. erinacea, while 3 was present in minor amounts (19). It is important to note that although lupeol is commercially available, calenduladiol, a triterpenoid with the uncommon feature of being hydroxylated at C-16, is not.

Recently, several hydroximinosteroids and sulfated analogs have been synthesized and evaluated for their cytotoxic activity against human tumor cell lines in vitro (20). These studies revealed that the presence of sulfate and oxime groups increase the cytotoxic activity against PC-3 and LNCaP cells, and highlighted the importance of the hydroxyl group configuration on the inhibition of these tumor cell lines. These results prompted us to synthesize lupane derivatives (4-22) from the natural most abundant triterpenes $\mathbf{1}$ and $\mathbf{2}$ obtained from the ethanolic extract of $C$. erinacea. To the best of our knowledge, this is the first evaluation of lupeol or calenduladiol semisynthetic derivatives as potential anticancer agents against human $\mathrm{PCa}$ cell lines. The in vitro cytotoxic activity of both natural and synthesized triterpenes was evaluated against two human prostate adenocarcinoma cell lines, PC-3 and LNCaP. Among the compounds tested, the effect of those that exhibited moderate cytotoxic activity $\left(\mathrm{IC}_{50}<70 \mu \mathrm{M}\right)$ on the migration of $\mathrm{PCa}$ cells using a wound-healing assay was also examined.

\section{Materials and Methods}

Melting points were determined on a Fisher-Johns apparatus (Reichert, Austria) and are uncorrected. Nuclear magnetic resonance (NMR) measurements, including COSY, HSQC, HMBC experiments, were carried out on Bruker ARX300 spectrometer (Bruker Corp, Billerica, MA, USA). NMR spectra were recorded in $\mathrm{CDCl} 3$ or MeOD. Chemical shifts are given in ppm $(\delta)$ with tetramethylsilane (TMS) as an internal standard. Electrospray ionization mass spectra were recorded using an Esquire 3000 ion trap mass spectrometer (Bruker, San Diego, CA, USA) equipped with a standard ESI/APCI source. Elemental analyses $(\mathrm{C}, \mathrm{H})$ were performed with an INC CE-440 Elemental Analyzer (Exeter Analytical, Inc, North Chelmsford, USA). Microwave-assisted reactions were carried out in a CEM Discover reactor (CEM Corp, Matthews, North Carolina, USA).

Silica gel 60 (0.2-0.63 mm, Merck KGaA, Darmstadt, Germany) was used for column chromatography. Silica gel 60 (70-230 mesh; Merck KGaA, Darmstadt, Germany) was used for flash chromatography. Analytical thin layer chromatography (TLC) was performed on Silicagel 60 F254 sheets $(0.2 \mathrm{~mm}$ thickness; Merck, Argentina). $p$-Anisaldehyde-acetic acid spray reagent (Mallinckrodt, New York, NY, USA) and UV light (254 and $366 \mathrm{~nm}$ ) were used for detection.

Solvents were dried and distilled in accordance with standard procedure (21). Lupeol (1) and calenduladiol (2), used as starting materials for the preparation of compounds 4-22, and heliantriol B2 (3) were obtained from aerial parts of $C$. erinacea subsp. erinacea as previously described $(19,22)$. Derivatives 5, 9-11, 14-16, 18 and 20-22 were prepared according to the synthesis previously reported by our group $(22,23)$.

All derivatives were rigorously characterized by NMR spectroscopy and mass spectrometry. The NMR data of derivatives $\mathbf{5}, \mathbf{8 - 1 1}, \mathbf{1 4 - 1 6}, \mathbf{1 8}$, and $\mathbf{2 0 - 2 2}$ were identical to those previously reported (22-24). In the case of compounds 6 and 7, we have completed the NMR data available in the literature $(25,26)$. Compounds $4,12,13,17$, and 19 are described here for the first time and bidimensional NMR spectra (COSY, HMBC, HSQC) were used for the unequivocal assignments of all carbons and representative protons.

General procedures for the preparation of sulfated compounds 4 , 12 and 13. A solution of $\mathrm{Me}_{3} \mathrm{~N} \cdot \mathrm{SO}_{3}$ and 1, 10 or 11 in dry dimethylformamide (DMF) was placed in a microwave-special closed vial and the solution was irradiated for $7 \mathrm{~min}$ at $150^{\circ} \mathrm{C}$ in a microwave reactor. The reaction mixture was then cooled to room temperature and quenched with water $(1 \mathrm{ml})$. After evaporation to dryness, the residue was eluted through Amberlite CG-120 (SigmaAldrich Chemie GmbH, Steinheim, Germany) (sodium form) with $\mathrm{MeOH}$, evaporated under reduced pressure and purified by column flash chromatography on silica gel with $\mathrm{CH}_{2} \mathrm{Cl}_{2} / \mathrm{MeOH}$ mixtures as eluent to afford the sulfated compounds.

Sodium 3 $\beta$-hydroxy-lup-20(29)-ene sulfate (4). Following the general procedure, a solution of $1(38.0 \mathrm{mg}, 0.09 \mathrm{mmol})$ in DMF (2 ml) was treated with $\mathrm{Me}_{3} \mathrm{~N} \bullet \mathrm{SO}_{3}(48.8 \mathrm{mg}, 0.36 \mathrm{mmol})$. Purification of the resulting crude by flash chromatography with $\mathrm{CH}_{2} \mathrm{Cl}_{2} / \mathrm{MeOH}$ (9:1) afforded $45.7 \mathrm{mg}$ (96\%) of compound $\mathbf{4}$ as a white amorphous solid, mp $142-143^{\circ} \mathrm{C} ;{ }^{1} \mathrm{H}-\mathrm{NMR}\left(300 \mathrm{MHz}, \mathrm{CD}_{3} \mathrm{OD}\right) \delta 4.68(1 \mathrm{H}, \mathrm{br}$ s, H-29a), 4.55 (1H, br s, H-29b), $3.92(1 \mathrm{H}, \mathrm{m}, \mathrm{H}-3 \alpha), 2.40(1 \mathrm{H}$, ddd, $J=11.0,11.0,5.7 \mathrm{~Hz}, \mathrm{H}-19), 2.08(1 \mathrm{H}, \mathrm{m}), 1.92(1 \mathrm{H}, \mathrm{m}), 1.72$ (3H, s, H-30), 1.35 (22H, m), 1.06 (3H, s, H-26), 1.01 (3H, s, H23), 0.98 (3H, s, H-27), 0.88 (3H, s, H-25), 0.81 (3H, s, H-28), 0.80 (3H, s, H-24); ${ }^{13} \mathrm{C}-\mathrm{NMR}\left(75 \mathrm{MHz}, \mathrm{CD}_{3} \mathrm{OD}\right) \delta 151.9$ (C-20), 110.1 (C-29), 87.8 (C-3), 57.2 (C-5), 51.8 (C-9), 49.5 (C-18), 49.4 (C-19), 44.1 (C-17), 44.0 (C-14), 42.1 (C-8), 41.0 (C-22), 39.8 (C-1), 39.6 (C-4), 39.5 (C-13), 38.2 (C-10), 36.7 (C-7), 35.5 (C-16), 30.9 (C2), 28.7 (C-15), 28.6 ( C-23), 26.4 (C-21), 25.4 (C-12), 22.1 (C-11), 19.5 (C-30), 19.4 (C-6), 18.4 (C-28), 16.8 (C-25), 16.7 (C-26), 16.6 (C-24), 15.0 (C-27); ESI-MS m/z 505 [M-Na] ${ }^{+}$. Anal. Calcd. for $\mathrm{C}_{30} \mathrm{H}_{49} \mathrm{NaO}_{4} \mathrm{~S}$ : C 68.15; H 9.34. Found: C 68.11; H 9.39. 

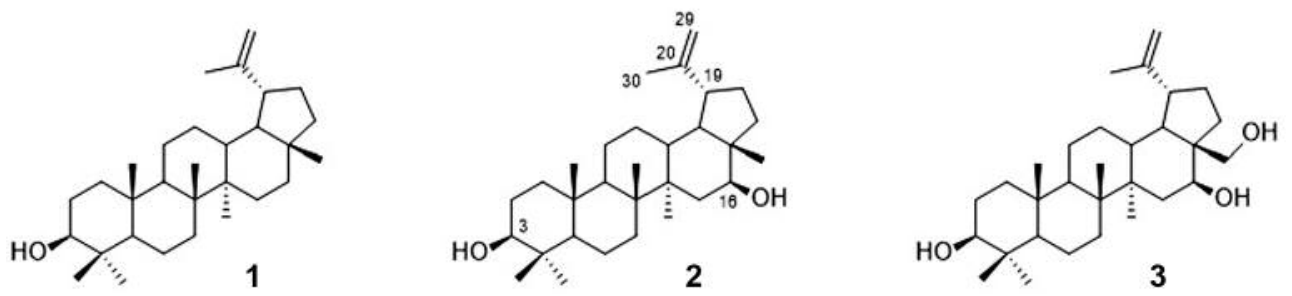

Figure 1. Structure of lupeol (1), calenduladiol (2) and heliantriol B2 (3).

Sodium 3 $\beta$-acetoxy-16 $\beta$-hydroxy-lup-20(29)-ene sulfate (12). Following the general procedure, a solution of $\mathbf{1 0}(10.0 \mathrm{mg}, 0.02$ mmol) in DMF $(2 \mathrm{ml})$ was treated with $\mathrm{Me}_{3} \mathrm{~N} \cdot \mathrm{SO}_{3}(10.8 \mathrm{mg}, 0.08$ mmol). Purification of the resulting crude by flash chromatography with $\mathrm{CH}_{2} \mathrm{Cl}_{2} / \mathrm{MeOH}$ (8.5:1.5) afforded $5.3 \mathrm{mg}(44 \%)$ of compound 12 as a white amorphous solid, mp $136-138{ }^{\circ} \mathrm{C} ;{ }^{1} \mathrm{H}-\mathrm{NMR}(300 \mathrm{MHz}$, $\left.\mathrm{CD}_{3} \mathrm{OD}\right) \delta 4.75(1 \mathrm{H}$, br s, H-29a), 4.63 (1H, brs, H-29b), $4.48(1 \mathrm{H}$, dd, $J=10.1,6.6 \mathrm{~Hz}, \mathrm{H}-3 \alpha), 4.37$ (1H, t, $J=7.4 \mathrm{~Hz}, \mathrm{H}-16 \alpha), 2.56(1 \mathrm{H}$, ddd, $J=11.6,11.6,6.2 \mathrm{~Hz}, \mathrm{H}-19), 1.76(3 \mathrm{H}, \mathrm{br} \mathrm{s}), 1.74(3 \mathrm{H}, \mathrm{s}, \mathrm{H}-$ $30), 1.65(5 \mathrm{H}, \mathrm{m}), 1.47(8 \mathrm{H}, \mathrm{m}), 1.33(3 \mathrm{H}, \mathrm{br} \mathrm{s}), 1.12(3 \mathrm{H}, \mathrm{s}, \mathrm{H}-26)$, $1.10(3 \mathrm{H}, \mathrm{s}, \mathrm{H}-27), 1.04(3 \mathrm{H}, \mathrm{m}), 0.94(3 \mathrm{H}, \mathrm{s}, \mathrm{H}-25), 0.90(3 \mathrm{H}, \mathrm{s}, \mathrm{H}-$ 24), 0.90 (3H, s, H-23), 0.89 (3H, s, H-28), OAc-3 [2.05 (3H, s)]; ${ }^{13} \mathrm{C}-\mathrm{NMR}\left(75 \mathrm{MHz}, \mathrm{CD}_{3} \mathrm{OD}\right) \delta 150.9$ (C-20), $110.0(\mathrm{C}-29), 85.9$ (C16), 82.1 (C-3), 56.5 (C-5), 50.9 (C-9), 50.9 (C-19), 49.2 (C-18), 48.9 (C-17), 45.3 (C-14), 42.2 (C-8), 38.9 (C-1), 38.9 (C-15), 38.7 (C-13), 38.4 (C-4), 37.9 (C-10), 35.6 (C-22), 35.4 (C-7), 30.7 (C21), 28.4 (C-23), 25.9 (C-12), 24.6 (C-2), 22.0 (C-11), 19.4 (C-30), 19.2 (C-6), 16.8 (C-24), 16.6 (C-25), 16.5 (C-26), 16.2 (C-27), 12.8 (C-28), OAc-3 [172.9 (s), 21.0 (c)]; ESI-MS m/z 563 [M-Na] ${ }^{+}$. Anal. Calcd. for $\mathrm{C}_{32} \mathrm{H}_{51} \mathrm{NaO}_{6} \mathrm{~S}$ : C 65.50; $\mathrm{H}$ 8.76. Found: C 65.57; $\mathrm{H} 8.78$.

Sodium 3 $\beta$-hydroxy-16 $\beta$-acetoxy-lup-20(29)-ene sulfate (13). Following the general procedure, a solution of $\mathbf{1 1}(8.0 \mathrm{mg}, 0.02$ mmol) in DMF $(2 \mathrm{ml})$ was treated with $\mathrm{Me}_{3} \mathrm{~N} \cdot \mathrm{SO}_{3}(10.8 \mathrm{mg}, 0.08$ $\mathrm{mmol}$ ). Purification of the resulting crude by flash chromatography with $\mathrm{CH}_{2} \mathrm{Cl}_{2} / \mathrm{MeOH}$ (8.5:1.5) afforded $3.3 \mathrm{mg}$ (27\%) of compound 13 as a white amorphous solid, mp $136-137^{\circ} \mathrm{C} ;{ }^{1} \mathrm{H}-\mathrm{NMR}(300 \mathrm{MHz}$, $\left.\mathrm{CD}_{3} \mathrm{OD}\right) \delta 4.91(1 \mathrm{H}$, brs, $\mathrm{H}-16 \alpha), 4.76(1 \mathrm{H}$, br s, H-29a), $4.64(1 \mathrm{H}$, br s, H-29b), $3.96(1 \mathrm{H}, \mathrm{dd}, J=11.5,4.4 \mathrm{~Hz}, \mathrm{H}-3 \alpha), 2.55(1 \mathrm{H}$, ddd, $J=11.6,11.1,5.6 \mathrm{~Hz}, \mathrm{H}-19), 1.76$ (2H, m), 1.74 (3H, s, H-30), 1.47 $(20 \mathrm{H}, \mathrm{m}), 1.12$ (6H, s, H-24, H-27), 1.06 (3H, s, H-23), 0.93 (3H, s, $\mathrm{H}-26), 0.92$ (3H, s, H-25), 0.85 (3H, s, H-28), OAc-16 [2.03 (3H, s)]; ${ }^{13} \mathrm{C}-\mathrm{NMR}\left(75 \mathrm{MHz}, \mathrm{CD}_{3} \mathrm{OD}\right) \delta 151.0$ (C-20), 110.7 (C-29), 87.5 (C-3), 80.7 (C-16), 57.2 (C-5), 51.3 (C-9), 50.0 (C-19), 49.2 (C-18), 48.9 (C-17), 45.3 (C-14), 42.2 (C-8), 39.8 (C-1), 39.6 (C-4), 38.8 (C13), 38.7 (C-15), 38.1 (C-10), 35.4 (C-22), 34.6 (C-7), 30.8 (C-21), 28.7 (C-23), 26.0 (C-12), 25.4 (C-2), 22.0 (C-11), 19.5 (C-30), 19.4 (C-6), 16.7 (C-25) 16.7 (C-26), 16.6 (C-27), 16.3 (C-24), 13.1 (C28), OAc-16 [172.6 (s), 21.2 (c)]; ESI-MS $m / z 563$ [M-Na] ${ }^{+}$. Anal. Calcd. for $\mathrm{C}_{32} \mathrm{H}_{51} \mathrm{NaO}_{6} \mathrm{~S}$ : C 65.50; $\mathrm{H}$ 8.76. Found: C 65.54; $\mathrm{H} 8.74$.

3E-Hydroxyimino lupane (6). To a solution of $5(40.0 \mathrm{mg}, 0.09$ $\mathrm{mmol})$ in EtOH $(2 \mathrm{ml})$ hydroxylamine hydrochloride $(18.8 \mathrm{mg}, 0.27$ $\mathrm{mmol})$ and a solution of sodium acetate $(11.6 \mathrm{mg}, 0.18 \mathrm{mmol})$ in water were added. The reaction mixture was left at room temperature for $36 \mathrm{~h}$, and then $\mathrm{EtOH}$ was evaporated. The residue was treated with water and extracted with $\mathrm{CH}_{2} \mathrm{Cl}_{2}(3 \times 5 \mathrm{ml})$. The combined organic extracts were dried over $\mathrm{MgSO}_{4}$, filtered, and concentrated. The solvent was removed and the residue was purified by flash chromatography on silica gel with hexane/AcOEt (9.5:0.5) afforded $12.9 \mathrm{mg}(31 \%)$ of compound 6 as a white amorphous solid; ${ }^{1} \mathrm{H}-\mathrm{NMR}\left(300 \mathrm{MHz}, \mathrm{CDCl}_{3}\right) \delta 4.69(1 \mathrm{H}, \mathrm{br} \mathrm{s}, \mathrm{H}-29 \mathrm{a}), 4.57(1 \mathrm{H}, \mathrm{br}$ s, H-29b), 2.96 (1H, m, H-2ß), 2.33 (3H, m, H-2a, H-6b, H-19), $1.66(3 \mathrm{H}, \mathrm{s}, \mathrm{H}-30), 1.44(21 \mathrm{H}, \mathrm{m}), 1.14(3 \mathrm{H}, \mathrm{s}, \mathrm{H}-23), 1.06(3 \mathrm{H}, \mathrm{s}$, H-24), 1.04 (3H, s, H-25), 0.93 (6H, s, H-26, H-27), 0.79 (3H, s, $\mathrm{H}-28)$. NOH $[8.26(1 \mathrm{H}, \mathrm{s})] ;{ }^{13} \mathrm{C}-\mathrm{NMR}\left(75 \mathrm{MHz}, \mathrm{CDCl}_{3}\right) \delta 167.4$ (C-3), 151.0 (C-20), 109.5 (C-29), 55.6 (C-5), 50.2 (C-9), 48.4 (C18), 48.1 (C-19), 43.1 (C-17), 43.1 (C-14), 41.0 (C-8), 40.4 (C-22), 38.9 (C-1), 38.9 (C-4), 38.3 (C-13), 37.4 (C-10), 35.7 (C-16), 34.5 (C-7), 30.0 (C-21), 27.6 (C-23), 27.6 (C-2), 27.6 (C-15), 25.3 (C12), 23.0 (C-24), 21.7 (C-11), 19.8 (C-30), 18.2 (C-6), 18.2 (C-28), 16.1 (C-26), 16.1 (C-25), 14.6 (C-27).

Lup-20(29)-en-3 $\beta$-amine (7b). A solution of 6 (18.0 mg, $0.04 \mathrm{mmol})$ in dry tetrahydrofuran (THF) $(5 \mathrm{ml})$ was added to a solution of $\mathrm{LiAlH}_{4}$ in THF $(0.40 \mathrm{mmol}, 15.2 \mathrm{mg}, 5 \mathrm{ml})$. The reaction mixture was refluxed for $7 \mathrm{~h}$ until disappearance of the starting material and then treated with a saturated solution of ammonium chloride. The aqueous phase was extracted with $\mathrm{CH}_{2} \mathrm{Cl}_{2}(3 \times 5 \mathrm{ml})$. The combined organic extracts were dried over $\mathrm{CaCl}_{2}$, filtered, and concentrated. The residue was purified by flash chromatography with $\mathrm{CH}_{2} \mathrm{Cl}_{2} / \mathrm{MeOH}(8: 2)$ afforded $4.3 \mathrm{mg}(25 \%)$ of compound $7 \mathbf{b} ;{ }^{1} \mathrm{H}-$ NMR $\left(300 \mathrm{MHz}, \mathrm{CD}_{3} \mathrm{OD}\right) \delta 4.72(1 \mathrm{H}$, brs, $\mathrm{H}-29 \mathrm{a}), 4.60(1 \mathrm{H}$, brs, H-29b), $2.90(1 \mathrm{H}, \mathrm{dd}, J=10.7,4.9 \mathrm{~Hz}, \mathrm{H}-3 \alpha), 2.44(1 \mathrm{H}$, ddd, $J=11.0,11.0,5.5 \mathrm{~Hz}, \mathrm{H}-19), 1.72$ (3H, s, H-30), $1.44(25 \mathrm{H}, \mathrm{m}), 1.03$ (3H, s, H-26), 0.98 (3H, s, H-23), 0.95 (3H, s, H-27), 0.83 (3H, s, $\mathrm{H}-25), 0.79$ (3H, s, H-28), $0.76(3 \mathrm{H}, \mathrm{s}, \mathrm{H}-24) ;{ }^{3} \mathrm{C}-\mathrm{NMR}(75 \mathrm{MHz}$, $\left.\mathrm{CD}_{3} \mathrm{OD}\right) \delta 151.9(\mathrm{C}-20), 110.1$ (C-29), 61.4 (C-3), 56.8 (C-5), 51.7 (C-9), 50.1 (C-18), 49.4 (C-19), 43.5 (C-17), 43.3 (C-14), 41.0 (C8), 40.6 (C-22), 39.5 (C-1), 39.4 (C-4), 38.2 (C-13), 37.6 (C-10), 35.5 (C-16), 35.3 (C-7), 30.9 (C-2), 28.6 (C-21), 28.2 (C-15), 28.2 (C-23), 24.6 (C-12), 21.8 (C-11), 19.3 (C-30), 18.4 (C-6), 18.1 (C28), 16.5 (C-25), 16.2 (C-26), 15.1 (C-24), 15.0 (C-27).

Lup-20(29)-en-3a-ol (8). A solution of 5 (50.0 mg, $0.12 \mathrm{mmol})$ in dry $\mathrm{MeOH}(20 \mathrm{ml})$, was treated with $\mathrm{NaBH}_{4}(50.0 \mathrm{mg}, 1.32 \mathrm{mmol})$. The reaction mixture was stirred at room temperature for $3 \mathrm{~h}$ until disappearance of the starting material verified by TLC. Then, the mixture was quenched with water $(20 \mathrm{ml})$ and $\mathrm{CH}_{2} \mathrm{Cl}_{2}(20 \mathrm{ml})$, observing the appearance of a white solid, and filtered. The organic phase was dried over $\mathrm{MgSO}_{4}$, filtered, and concentrated. The residue was purified by flash chromatography with hexane/AcOEt (9.5:0.5) afforded $2.3 \mathrm{mg}$ (5\%) of compound $\mathbf{8}$ and $27.0 \mathrm{mg}(54 \%)$ of lupeol (1). Spectroscopic and spectrometric data of $\mathbf{8}$ were identical to those reported for epilupeol (24). 
General procedures for the preparation of oximes 17 and 19. To a solution of $\mathbf{1 6}$ or $\mathbf{1 8}$ in $\mathrm{EtOH}$, hydroxylamine hydrochloride and a solution of sodium acetate in water were added. The reaction mixture was heated to reflux for $18 \mathrm{~h}$, and then EtOH was evaporated. The residue was treated with water and extracted with $\mathrm{CH}_{2} \mathrm{Cl}_{2}(3 \times 5 \mathrm{ml})$. The combined organic extracts were dried over $\mathrm{MgSO}_{4}$, filtered, and concentrated. The solvent was removed and the residue was purified by flash chromatography on silica gel with hexane/AcOEt mixtures as eluent to afford the oximes.

$3 E, 16 E$-Dihydroxyimino lupane (17). Following the general procedure, to a solution of $\mathbf{1 6}(45.0 \mathrm{mg}, 0.10 \mathrm{mmol})$ in EtOH (2 $\mathrm{ml})$, hydroxylamine hydrochloride $(39.8 \mathrm{mg}, 0.60 \mathrm{mmol})$ and a solution of sodium acetate $(33.8 \mathrm{mg}, 0.40 \mathrm{mmol})$ in water were added. Purification of the resulting crude by flash chromatography with hexane/AcOEt (8.5:1.5) afforded $16.8 \mathrm{mg} \mathrm{(35 \% )} \mathrm{of}$ compound 17 as a white amorphous solid, mp $179-180^{\circ} \mathrm{C} ;{ }^{1} \mathrm{H}-$ NMR $\left(300 \mathrm{MHz}, \mathrm{CDCl}_{3}\right) \delta 4.72(1 \mathrm{H}$, br s, H-29a), $4.61(1 \mathrm{H}, \mathrm{br}$ s, H-29b), $3.16(1 \mathrm{H}, \mathrm{dt}, J=15.3,4.7 \mathrm{~Hz}, \mathrm{H}-2 \beta), 2.90(1 \mathrm{H}, \mathrm{d}$, $J=13.4 \mathrm{~Hz}, \mathrm{H}-15 \beta), 2.52$ (1H, ddd, $J=10.9,10.9,5.6 \mathrm{~Hz}, \mathrm{H}-19)$, $2.01(4 \mathrm{H}, \mathrm{m}), 1.79(3 \mathrm{H}, \mathrm{m}), 1.65(3 \mathrm{H}, \mathrm{s}, \mathrm{H}-30), 1.47(11 \mathrm{H}, \mathrm{m})$, $1.27(2 \mathrm{H}, \mathrm{m}), 1.12$ (6H, s, H-23, H-26), 1.03 (3H, s, H-24), 1.01 (3H, s, H-28), 0.99 (3H, s, H-25), 0.89 (3H, s, H-27), NOH [9.68 $(1 \mathrm{H}, \mathrm{s}), 9.58(1 \mathrm{H}, \mathrm{s})] ;{ }^{13} \mathrm{C}-\mathrm{NMR}\left(75 \mathrm{MHz}, \mathrm{CDCl}_{3}\right) \delta 167.2(\mathrm{C}-3)$, 165.2 (C-16), 149.6 (C-20), 110.5 (C-29), 56.7 (C-5), 50.1 (C-18), 50.0 (C-9), 48.8 (C-17), 47.4 (C-19), 46.1 (C-14), 41.1 (C-8), 41.1 (C-4), 39.7 (C-1), 37.9 (C-13), 37.5 (C-10), 34.5 (C-7), 33.3 (C22), 29.6 (C-21), 27.4 (C-15), 26.4 (C-23), 24.8 (C-12), 22.6 (C24), 20.9 (C-11), 19.2 (C-30), 18.9 (C-2), 18.9 (C-28), 17.2 (C-6), 16.6 (C-26), 15.8 (C-25), 15.1 (C-27); ESI-MS m/z 467 [M-H] $]^{+}$

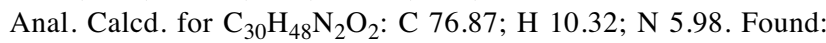
C 76.80; H 10.35; N 5.94.

$3 E, 16 E, 30-$ Trihydroxyimino lupane (19). Following the general procedure, a solution of $\mathbf{1 8}(20.0 \mathrm{mg}, 0.04 \mathrm{mmol})$ in EtOH $(2 \mathrm{ml})$, hydroxylamine hydrochloride $(27.9 \mathrm{mg}, 0.42 \mathrm{mmol})$ and a solution of sodium acetate $(7.5 \mathrm{mg}, 0.08 \mathrm{mmol})$ in water were added. Purification of the resulting crude by flash chromatography with hexane/AcOEt (7.5:2.5) afforded $6.7 \mathrm{mg} \mathrm{(31 \% )} \mathrm{of} \mathrm{compound} 19$ as a white amorphous solid, mp 201-202 ${ }^{\circ} \mathrm{C} ;{ }^{1} \mathrm{H}-\mathrm{NMR}(300 \mathrm{MHz}$, $\left.\mathrm{CDCl}_{3}\right) \delta 7.71(1 \mathrm{H}, \mathrm{s}, \mathrm{H}-30), 5.38(1 \mathrm{H}$, br s, H-29a), $5.20(1 \mathrm{H}, \mathrm{br} \mathrm{s}$,

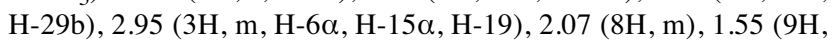
$\mathrm{m}), 1.33(3 \mathrm{H}, \mathrm{s}), 1.20(3 \mathrm{H}, \mathrm{s}, \mathrm{H}-26), 1.17(3 \mathrm{H}, \mathrm{s}, \mathrm{H}-23), 1.08(3 \mathrm{H}$, s, H-24), 1.06 (3H, s, H-28), 0.99 (3H, s, H-25), 0.92 (3H, s, H-27); ${ }^{13} \mathrm{C}-\mathrm{NMR}\left(75 \mathrm{MHz}, \mathrm{CDCl}_{3}\right) \delta 167.2(\mathrm{C}-3), 166.4(\mathrm{C}-16), 152.8(\mathrm{C}-$ 30), 150.7 (C-20), 120.4 (C-29), 56.6 (C-5), 51.1 (C-18), 49.8 (C9), 49.6 (C-19), 46.5 (C-8), 46.5 (C-17), 42.1 (C-14), 41.0 (C-4), 39.7 (C-1), 39.2 (C-13), 38.2 (C-10), 35.1 (C-7), 34.2 (C-22), 30.7 (C-12), 28.2 (C-15), 28.2 (C-23), 27.7 (C-21), 23.5 (C-24), 22.2 (C2), 20.2 (C-11), 19.3 (C-28), 17.9 (C-6), 16.8 (C-26), 16.2 (C-25), 15.3 (C-27); ESI-MS m/z, 497 [M] ${ }^{+}$(47), 482 (11), 480 (100), 462 (24); Anal. Calcd. for $\mathrm{C}_{30} \mathrm{H}_{47} \mathrm{~N}_{3} \mathrm{O}_{3}$ : C 72.40; $\mathrm{H} 9.52 ; \mathrm{N} 8.44$. Found: C 72.30; H 9.50; N 8.34.

\section{Cytotoxic activity}

Cell culture and reagents. Human prostate cancer cell lines PC-3 and $\mathrm{LNCaP}$ were obtained from the American Type Culture Collection (Manassas, VA, USA). Cells were grown in RPMI 1640 medium (EMEVE Medios, Lab MicroVet, Buenos Aires, Argentina) supplemented with $10 \%$ fetal bovine serum (FBS) (Natocor, Córdoba, Argentina) and antibiotics (Invitrogen), in a humidified atmosphere $\left(95 \%\right.$ air, $\left.5 \% \mathrm{CO}_{2}, 37^{\circ} \mathrm{C}\right)$.
Cell viability assay. PC -3 cells $\left(1 \times 10^{4}\right.$ cells $\left./ 100 \mu \mathrm{l}\right)$ and $\mathrm{LNCaP}$ $\left(3 \times 10^{4}\right.$ cells $\left./ 100 \mu \mathrm{l}\right)$ were seeded into each well of a 96-well microtiter plate. After incubation for $24 \mathrm{~h}$, the media were aspirated and replaced with 100 of serum-free medium containing different concentrations of each compound. Triplicate wells were prepared for each individual dose.

MTS cell viability analysis was performed $24 \mathrm{~h}$ post treatment using the Cell Titer 96 AQueous One Solution Proliferation Assay System (Promega Corp, Madison, WI, USA); in which viable cells convert 3-(4,5-dimethylthiazol-2-yl)-5-(3-carboxymethoxyphenyl)-2(4-sulfophenyl)-2H-tetrazolium (MTS tetrazolium) into a formazancolored product (OD490 nm). Following the manufacturer's instructions, $20 \mu \mathrm{l}$ of MTS reagent were added to each well and cells were incubated at $37^{\circ} \mathrm{C}$ for $1 \mathrm{~h}$. Absorbance was detected at $490 \mathrm{~nm}$ on a Thermo Scientific Multiskan FC plate reader (Thermo Fisher Scientific, Waltham, USA). The $\mathrm{IC}_{50}$ value was defined as the concentration of tested compound resulting in a $50 \%$ reduction in cell viability compared to vehicle-treated (dimethyl sulfoxide) cells.

Wound-healing assay. The effect of compounds on cell migration was assessed in PC-3 and LNCaP cells using a wound-healing assay. PC-3 $\left(1.0 \times 10^{4}\right.$ cells/well $)$ and $\mathrm{LNCaP}\left(3.0 \times 10^{4}\right.$ cells/well $)$ cells were cultured in a 96 -well plate to reach $100 \%$ confluence. A vertical scratch across the well was made with a $200 \mu$ l pipette tip (time 0 ), followed by two washes with phosphate-buffered saline (PBS). The test compound was then added to each well. RPMI 1640 with the same corresponding percentage of dimethyl sulfoxide was used for control wells. Microscopy images were taken at 0,18 and $23 \mathrm{~h}$ to assess cell migration visually. Images were captured using an inverted phase-contrast microscope (Olympus CKX-41, 4xobjective; Bioanalitica, Buenos Aires, Argentina). Each compound was added in duplicate wells, and each experiment was repeated twice. The area of wound was quantified by Image J software (http:// rsb.info.nih.gov) using the polygon selection mode. The migration of cells toward the wound was expressed as the percentage of wound closure: wound closure $(\%)=\left[\left(\mathrm{At}_{0 \mathrm{~h}}-\mathrm{At} \Delta \mathrm{h}\right) / \mathrm{At}_{0 \mathrm{~h}}\right] \times 100 \%$, where, $\mathrm{At}_{0 \mathrm{~h}}$ was the area of wound measured immediately after scratching, and At $\Delta \mathrm{h}$ was the area of wound measured 18 or $23 \mathrm{~h}$ after scratching (27).

Statistical analysis. Statistical analysis was performed using Graph Pad Prism Software (La Jolla, CA, USA). Data are expressed as mean \pm standard deviation. ANOVA with Dunn's post test was employed for statistical analysis of wound-healing assay. Statistical significance was established at $p<0.05$.

\section{Results}

Natural triterpenoids 1-3 were obtained from the ethanolic extract of the aerial parts of C. erinacea as previously reported (Figure 1) (19). The first series of derivatives (4-8) was synthesized according to the reaction sequence shown in Figure 2, using lupeol (1) as the starting material. Treatment of $\mathbf{1}$ with 4 equivalents of trimethylamine-sulfur trioxide complex $\left(\mathrm{Me}_{3} \mathrm{~N} \cdot \mathrm{SO}_{3}\right)$ for $7 \mathrm{~min}$ at $150^{\circ} \mathrm{C}$ in a microwave reactor afforded the corresponding ammonium sulfate, which was transformed via ion exchange into the sodium salt 4 in excellent yield (96\%), as described previously (23). The ${ }^{1} \mathrm{H}-\mathrm{NMR}$ spectrum of $\mathbf{4}$ showed a 


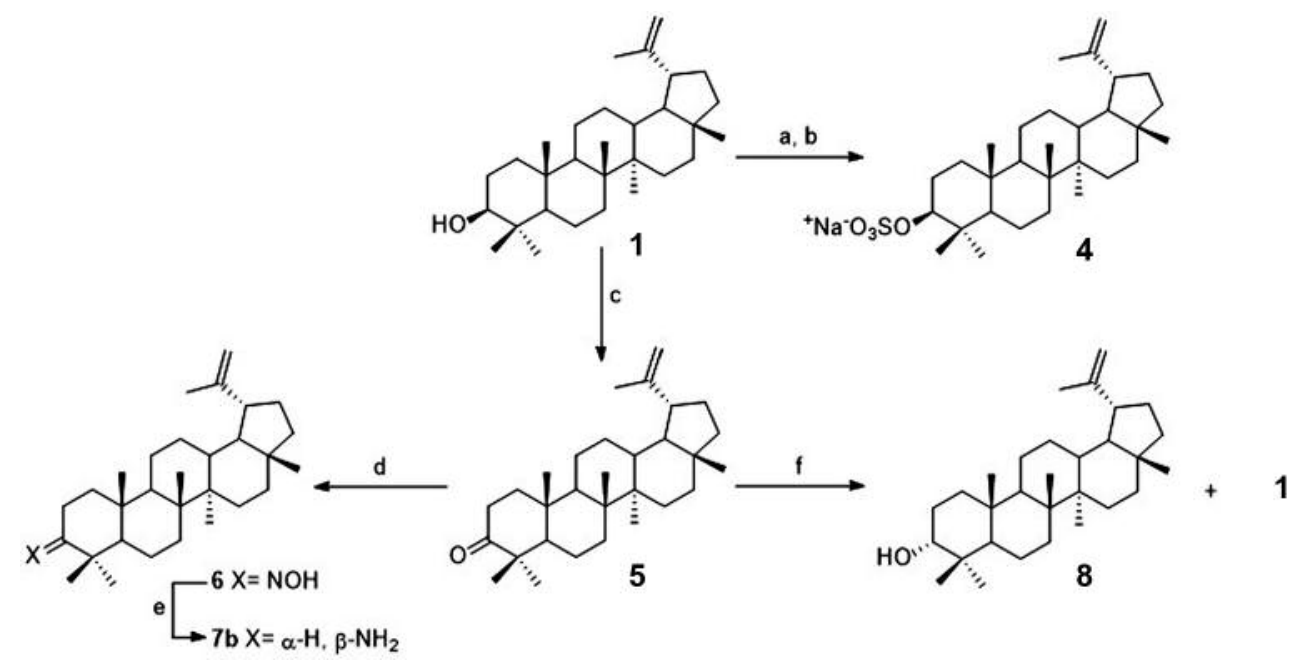

Figure 2. Synthesis of compounds 4-8. Reagents and conditions: (a) 4 equiv. $\mathrm{Me}_{3} \mathrm{~N} \cdot \mathrm{SO}_{3}, \mathrm{DMF}, 7 \mathrm{~min}, 150^{\circ} \mathrm{C}$, microwave; (b) Amberlite CG-120 $(\mathrm{MeOH}) ;\left(\right.$ c) Jones reagent, acetone, $\mathrm{O}^{\circ} \mathrm{C}$; (d) $\mathrm{NH}_{2} \mathrm{OH} \bullet \mathrm{HCl}$, NaOAc, EtOH/H $\mathrm{H}_{2} \mathrm{O}$; (e) $\mathrm{LiAlH}_{4}, \mathrm{THF}$; (f) $\mathrm{NaBH}_{4}, \mathrm{MeOH}$.

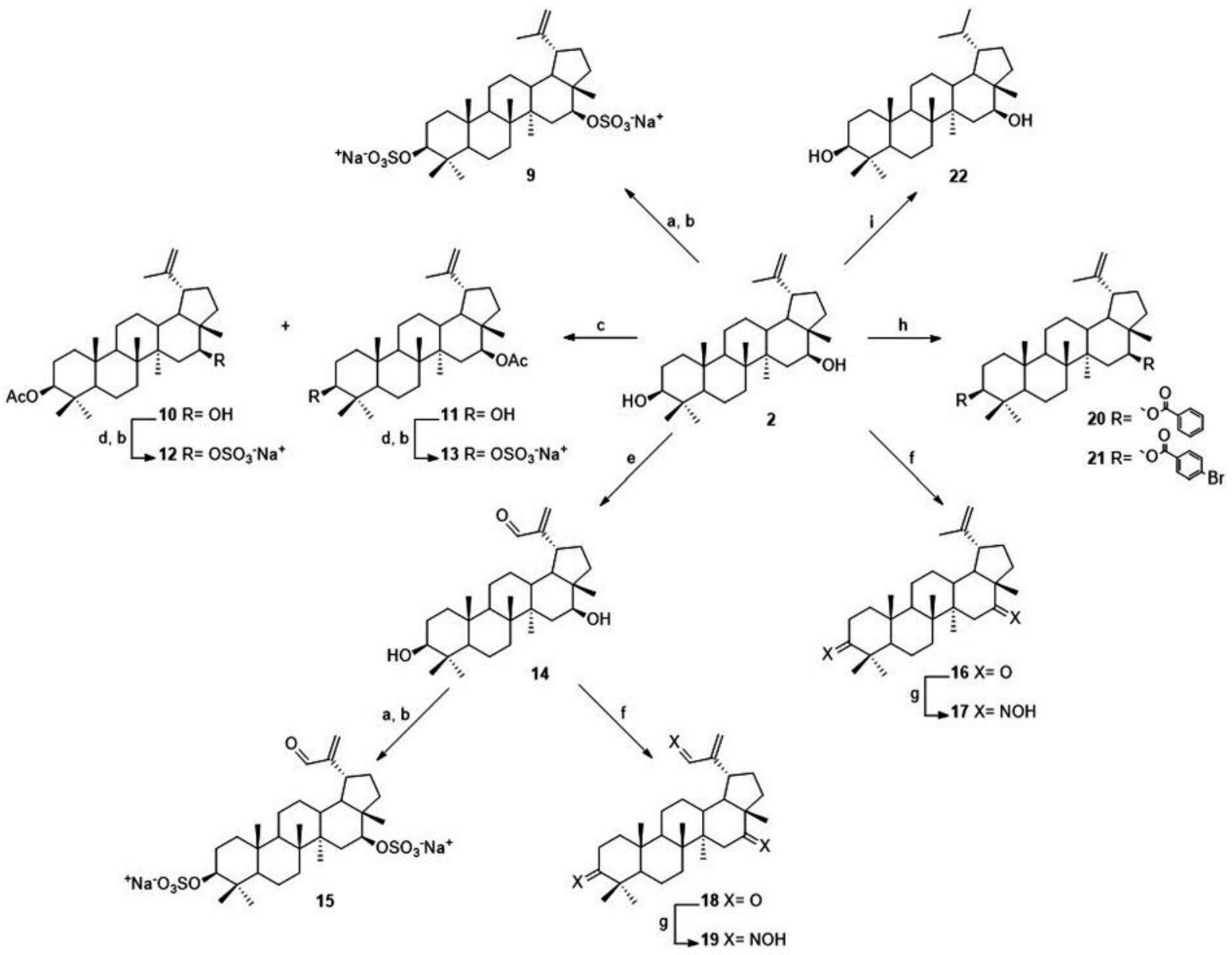

Figure 3. Synthesis of compounds 9-17. Reagents and conditions: (a) 8 equiv. $\mathrm{Me}_{3} \mathrm{~N}_{\mathrm{SO}}, \mathrm{DMF}, 7 \mathrm{~min}, 150^{\circ} \mathrm{C}$, microwave; (b) Amberlite CG-120 ( $\mathrm{MeOH}$ ); (c) AcO, Py, DMAP, DCM; (d) 4 equiv. $\mathrm{Me}_{3} \mathrm{~N}^{\circ} \mathrm{SO}_{3}, \mathrm{DMF}, 7 \mathrm{~min}, 150^{\circ} \mathrm{C}$, microwave; (e) $\mathrm{SeO}$, EtOH, reflux; ( $f$ ) Jones reagent, acetone, $\mathrm{O}^{\circ} \mathrm{C}$; (g) $\mathrm{NH}_{2} \mathrm{OH} \bullet \mathrm{HCl}, \mathrm{NaOAc}, \mathrm{EtOH} / \mathrm{H}_{2} \mathrm{O}$; (h) ArCOCl, Py, DMAP, DCM; (i) $\mathrm{H}_{2}, \mathrm{Pd} / \mathrm{C}, \mathrm{EtOAc}$. 
multiplet at $3.96 \mathrm{ppm}(\mathrm{H}-3 \alpha)$, geminal to the sulfate group at C-3 (87.6 ppm) as determined by analysis of ${ }^{13} \mathrm{C}$ NMR and HSQC spectra, which confirmed the presence of a sulfate group at C-3 in $\beta$ orientation.

Oxidation of 1 with Jones reagent in acetone rendered lupenone (5) in almost quantitative yield, while the reaction of 5 with hydroxylamine hydrochloride $\left(\mathrm{NH}_{2} \mathrm{OH} \bullet \mathrm{HCl}\right)$ provided oxime 6 in $31 \%$ yield. From this synthesis, the $E$ isomer was obtained as the only product, as was clearly seen on TLC and confirmed by analysis of proton and carbon NMR chemical shifts. The ${ }^{1} \mathrm{H}$-NMR spectrum showed a multiplet at $2.96 \mathrm{ppm}(\mathrm{H}-2 \beta)$, which was shifted downfield due to the deshielding effect of the hydroxyl oxygen of the oxime. This assignment was confirmed by the correlation between $\mathrm{H}-2 \beta$ and C-3 (167.4 ppm) in the HMBC spectra of the compound. The ${ }^{1} \mathrm{H}$-NMR spectrum also showed the presence of a singlet at $8.26 \mathrm{ppm}$ for the proton of the $\mathrm{NOH}$ group.

The reaction of 6 with $\mathrm{LiAlH}_{4}$ in THF gave a mixture of amines $(3 \alpha)-7 \mathbf{a}$ and $(3 \beta)-7 \mathbf{b}$ in a $27: 73$ ratio, which were separated by flash chromatography. The $\alpha$ or $\beta$ orientation for the amino group attached to $\mathrm{C}-3$ was established from their ${ }^{1} \mathrm{H}-\mathrm{NMR}$ spectrum. However, due to the limited amount of sample, the complete spectroscopic characterization and biological activity of amine 7a was not possible. Hydrogenation of ketone 5 using $\mathrm{NaBH}_{4}$ led to a 10:90 mixture of the $\alpha$ - and $\beta$-epimers of lupeol (compounds 8 and 1, respectively), according to the ${ }^{1} \mathrm{H}-\mathrm{NMR}$ spectrum. Both alcohols were separated and purified by flash chromatography.

The second series of derivatives (9-22) were prepared from 2 , following the reaction sequence shown in Figure 3. Sulfation of 2 with 8 equivalents of $\mathrm{Me}_{3} \mathrm{~N} \cdot \mathrm{SO}_{3}$ for $7 \mathrm{~min}$ at $150^{\circ} \mathrm{C}$ in a microwave reactor and further transformation via ion exchange afforded disodium disulfate 9 in $93 \%$ yield. Esterification of diol 2 with 1 equivalent of acetic anhydride yielded a 1:1 mixture of the monoacetates $\mathbf{1 0}$ and $\mathbf{1 1}$. Both monoacetylated derivatives were separated and purified by flash chromatography. Sulfation of $\mathbf{1 0}$ and $\mathbf{1 1}$ with 4 equivalents of $\mathrm{Me}_{3} \mathrm{~N} \cdot \mathrm{SO}_{3}$ rendered the corresponding monosulfates $12(44 \%$ yield) and $\mathbf{1 3}$ (27\% yield), respectively. The ${ }^{1} \mathrm{H}-\mathrm{NMR}$ spectrum of $\mathbf{1 2}$ showed a double doublet at $4.48 \mathrm{ppm}$ corresponding to the presence of an acetoxy group at C-3 and a triplet at 4.37 ppm assignable to $\mathrm{H}-16$ with a sulfate group attached to C-16. This was in accordance with the chemical shifts observed for C-3 (82.1 ppm) and C-16 (85.9 ppm), which were unequivocally assigned from the HSQC and HMBC spectra. ${ }^{1} \mathrm{H}$ - and ${ }^{13} \mathrm{C}$-NMR data of compound $\mathbf{1 3}$ confirmed that, in this case, the sulfate group was attached to $\mathrm{C}-3$ while the acetoxy group was at C-16 $\left[\delta_{\mathrm{H}} 3.96(\mathrm{dd}, \mathrm{H}-3 \alpha), \delta_{\mathrm{H}} 4.91(\mathrm{br} \mathrm{s}, \mathrm{H}-16 \alpha)\right.$, $\delta_{\mathrm{C}} 87.5(\mathrm{C}-3)$ and $\left.\delta_{\mathrm{C}} 80.7(\mathrm{C}-16)\right]$.

Allylic oxidation of 2 with 2.5 equivalents of $\mathrm{SeO}_{2}$ was carried out for the introduction of formyl functionality at the C-30 position, yielding compound $\mathbf{1 4}$ in excellent yield (97\%). Subsequent sulfation of $\mathbf{1 4}$ with 8 equivalents of
Table I. Cytotoxicity of triterpenes 1-22 after $24 \mathrm{~h}$ incubation with PC3 and LNCaP prostate cancer cells as measured with toxicity assay.

\begin{tabular}{lcc}
\hline Compound & \multicolumn{2}{c}{$\mathrm{IC}_{50}(\mu \mathrm{M})$} \\
\cline { 2 - 3 } & $\mathrm{PC}-3$ & $\mathrm{LNCaP}$ \\
\hline $\mathbf{1}$ & $>70$ & $>70$ \\
$\mathbf{2}$ & $>70$ & $>70$ \\
$\mathbf{3}$ & $46.58 \pm 1.10$ & $42.81 \pm 1.06$ \\
$\mathbf{4}$ & $16.13 \pm 1.10$ & $7.43 \pm 1.32$ \\
$\mathbf{5}$ & $>70$ & $>70$ \\
$\mathbf{6}$ & $>70$ & $>70$ \\
$\mathbf{7 b}$ & $32.12 \pm 1.09$ & $42.09 \pm 1.16$ \\
$\mathbf{8}$ & $>70$ & $>70$ \\
$\mathbf{9}$ & $60.70 \pm 1.08$ & $45.79 \pm 1.06$ \\
$\mathbf{1 0}$ & $>70$ & $>70$ \\
$\mathbf{1 1}$ & $>70$ & $>70$ \\
$\mathbf{1 2}$ & $44.93 \pm 1.14$ & $38.43 \pm 1.07$ \\
$\mathbf{1 3}$ & $49.21 \pm 1.05$ & $41.13 \pm 1.04$ \\
$\mathbf{1 4}$ & $>70$ & $>70$ \\
$\mathbf{1 5}$ & $60.07 \pm 1.07$ & $>70$ \\
$\mathbf{1 6}$ & $>70$ & $>70$ \\
$\mathbf{1 7}$ & $>70$ & $>70$ \\
$\mathbf{1 8}$ & $>70$ & $>70$ \\
$\mathbf{1 9}$ & $>70$ & $>70$ \\
$\mathbf{2 0}$ & $>70$ & $>70$ \\
$\mathbf{2 1}$ & $>70$ & $>70$ \\
$\mathbf{2 2}$ & $>70$ & $>70$ \\
Doxorubicin & $1.63 \pm 0.01$ & $1.89 \pm 0.01$ \\
\hline & &
\end{tabular}

$\mathrm{IC}_{50}$ : Concentration resulting in a $50 \%$ reduction in cell viability compared to vehicle-treated cells. Data are the mean \pm S.D. obtained on the basis of triplicate assays.

$\mathrm{Me}_{3} \mathrm{~N} \cdot \mathrm{SO}_{3}$ afforded the disulfated analog 15 . Oxidation with Jones reagent of compound 2 yielded diketone 16, which in turn was converted in dioxime 17 (35\%) by treatment with $\mathrm{NH}_{2} \mathrm{OH} \bullet \mathrm{HCl}$ and heating under reflux. Analysis of proton and carbon NMR chemical shifts at C-2, C-3, C-15, and C16 confirmed the structure of $\mathbf{1 7}$. Resonances showing $\mathrm{H}$ $15 \beta$ as a doublet at $2.90 \mathrm{ppm}$ was shifted downfield due to the deshielding effect of the hydroxyl oxygen of the oxime of C-16, which was indicative of the $E$ configuration. This assignment was confirmed by the correlation between $\mathrm{H}-15 \beta$ and C-16 (165.2 ppm) in the HMBC spectra of compound 17. In addition, the signals belonging to $\mathrm{H}-2 \beta$ confirmed the $E$ configuration of the hydroxyimino group of $\mathrm{C}-3$, as described above for the oxime 6 . The ${ }^{1} \mathrm{H}$-NMR spectrum also showed the presence of two broad singlets at 9.68 and $9.58 \mathrm{ppm}$ for the protons of the NOH groups.

On the other hand, oxidation of compound $\mathbf{1 4}$ with Jones reagent rendered 3,16,30-trioxolupane $\mathbf{1 8}$, and reaction of compound 18 with $\mathrm{NH}_{2} \mathrm{OH} \bullet \mathrm{HCl}$ provided trioxime 19 (31\% yield). Analysis of proton and carbon NMR chemical shifts confirmed the $E$ configuration of the hydroxyimino groups of C-3 and C-16, as described above for the oxime 17. 
A Control vehicle

Compound 13

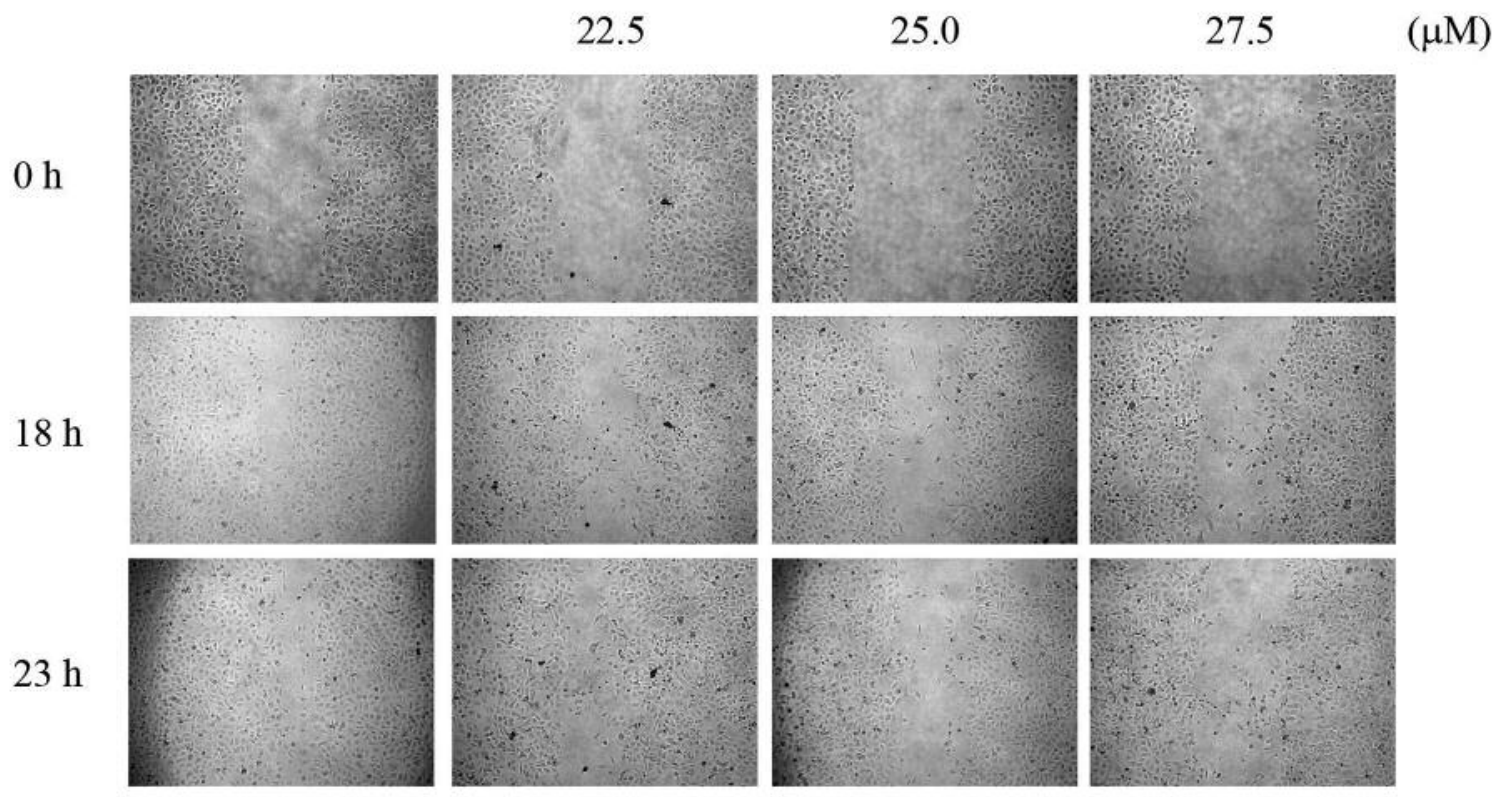

B

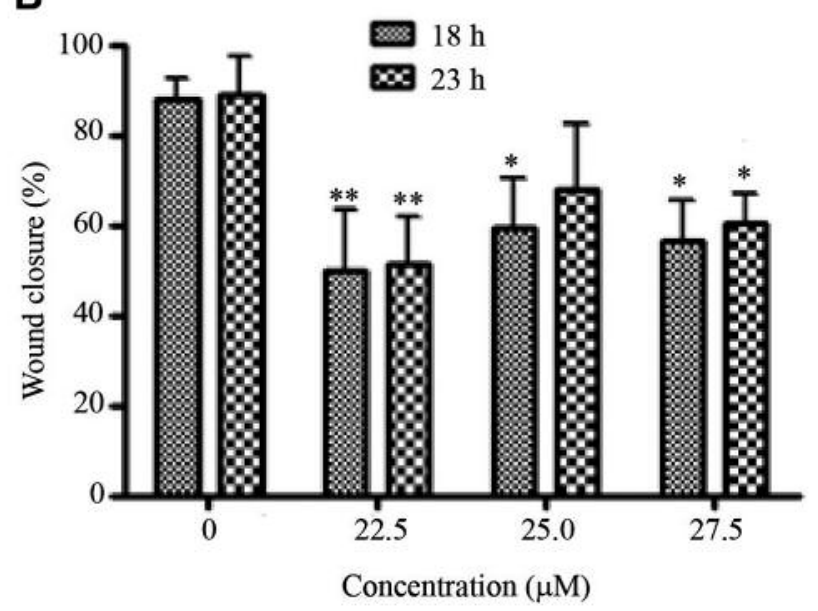

Figure 4. Compound 13 suppressed migration of PC-3 cells in vitro. A: Representative light microscopy images of wound closure (4X). Cells were grown to confluence, wounded and then incubated with different concentrations of 13. Images were captured at 0,18 and $23 \mathrm{~h}$ after wounding. B: Quantitative analysis of wound closure was performed using the Image J software and data are expressed as the mean \pm standard deviation. Compound 13 significantly inhibited PC-3 cell migration at $22.5 \mu \mathrm{M}$ compared with the control at 18 and $23 h\left({ }^{*} p<0.05\right.$ and $\left.* * p<0.001\right)$.

Treatment of diol 2 with the corresponding acyl chlorides in pyridine and DMAP, afforded the esters $\mathbf{2 0}$ (41\% yield) and $\mathbf{2 1}$ ( $42 \%$ yield), while reduction of the double bond of $\mathbf{2}$ was carried out by catalytic hydrogenation yielding the derivative 22 (65\% yield).

The lupeol derivatives 5-8 were identified by comparison of their spectroscopic data with those reported in the literature $(22,24-26)$. Calenduladiol derivatives 9-11, 14-16, 18 and 20-22 were identified by comparison of their spectroscopic data with those reported in our previous work $(22,23)$. Full structural elucidation of the new lupane derivatives $4,12,13,17$, and 19 was achieved by NMR and mass spectroscopy, and assignments were performed based on our analysis and related literature.

Cytotoxic activity. To determine the potential application of natural triterpenoids 1-3 and their semisynthetic derivatives 4-22 for the treatment of $\mathrm{PCa}$, their in vitro cytotoxic activity 
A Control vehicle

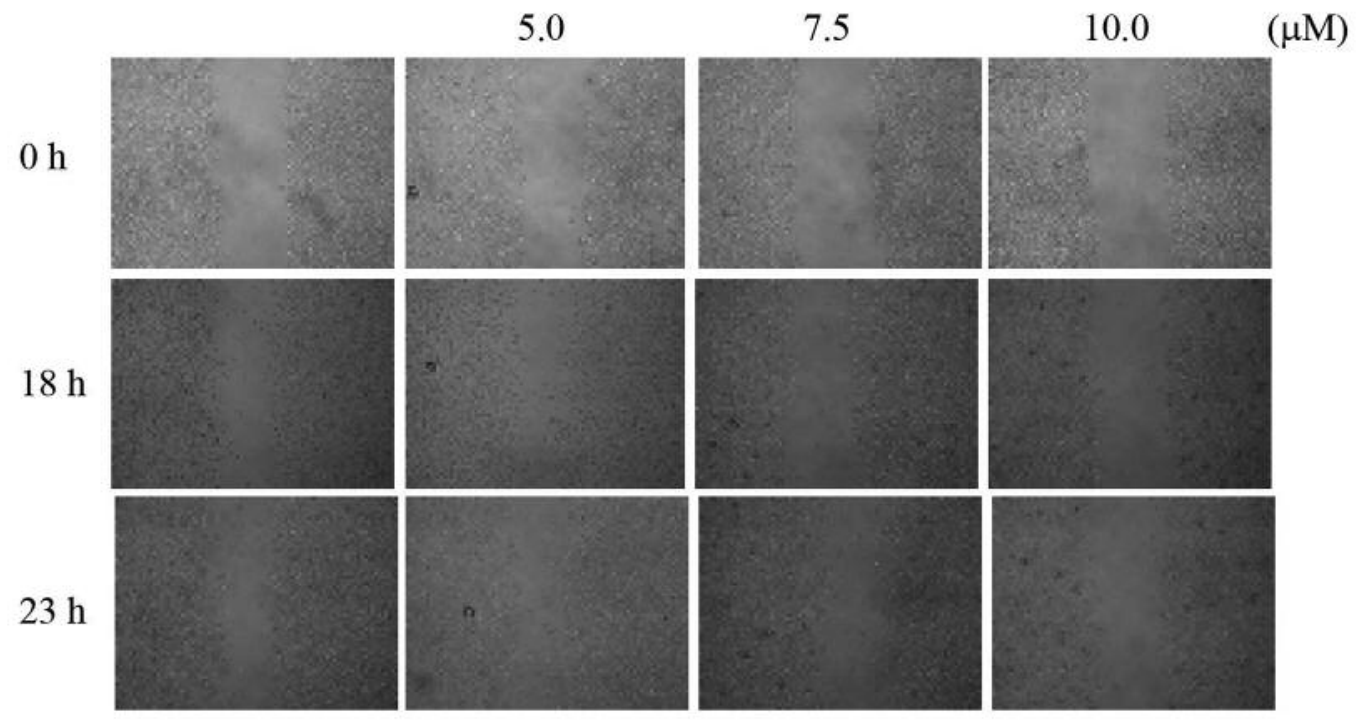

B

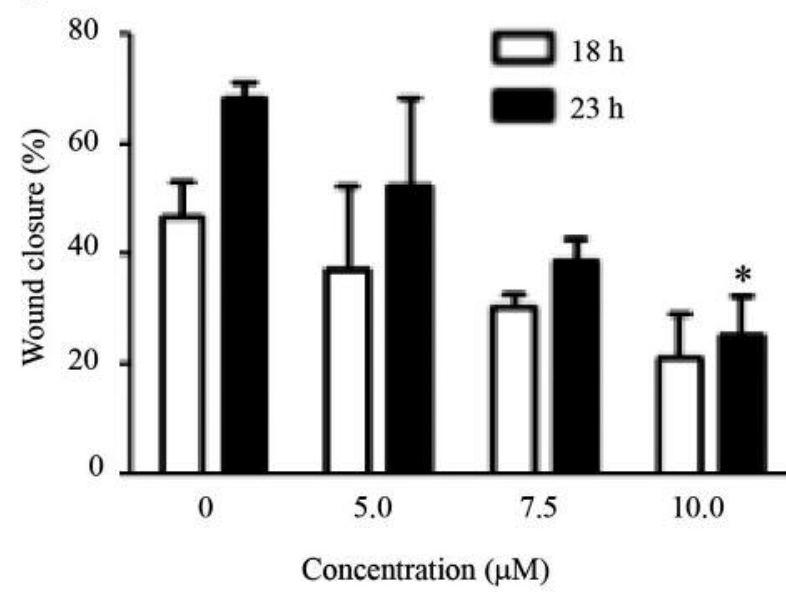

Figure 5. Heliantriol B2 (3) suppressed migration of LNCaP cells in vitro. A: Representative light microscopy images of wound closure (4X). Cells were grown to confluence, wounded and then incubated with different concentrations of 3 . Images were captured at 0,18 and $23 \mathrm{~h}$ after wounding. Note that the wound closure was suppressed by 3 in a dose-dependent manner. B: Quantitative analysis of wound closure was performed using Image $J$ software and data are expressed as the mean \pm standard deviation. Compound 3 significantly inhibited LNCaP cell migration at $10 \mu M$ respect compared with the control at $23 h(* p<0.05)$.

against two human prostate carcinoma cell lines, PC-3 (androgen-independent) and LNCaP (androgen-dependent), was evaluated. The results, expressed as $\mathrm{IC}_{50}$ values, are summarized in Table I. Cell lines were exposed for $24 \mathrm{~h}$ with the compounds at a range of 5-70 $\mu \mathrm{M}$. MTS one-step colorimetric assay was performed to test the cytotoxic potential and to determine $\mathrm{IC}_{50}$ doses. Doxorubicin was used as a reference anticancer drug.

Treatment of PC-3 and LNCaP cells with natural triterpenoids 1-3 resulted in dose- and time-dependent inhibition of cell growth for both cell lines (data not shown), as previously reported for lupeol $(12,13)$. Among these natural triterpenoids, tri-hydroxylated triterpene heliantriol B2 (3) showed the greatest cytotoxic effect following $24 \mathrm{~h}$ of exposure. These results are consistent with our previous report of cytotoxic activity against human leukemia cell lines for this triterpene (7).

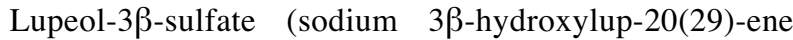
sulfate, 4), a new semisynthetic lupane, was the most active compound, with $\mathrm{IC}_{50}$ values of $16.13 \mu \mathrm{M}$ (PC-3) and 7.43 
A Control vehicle

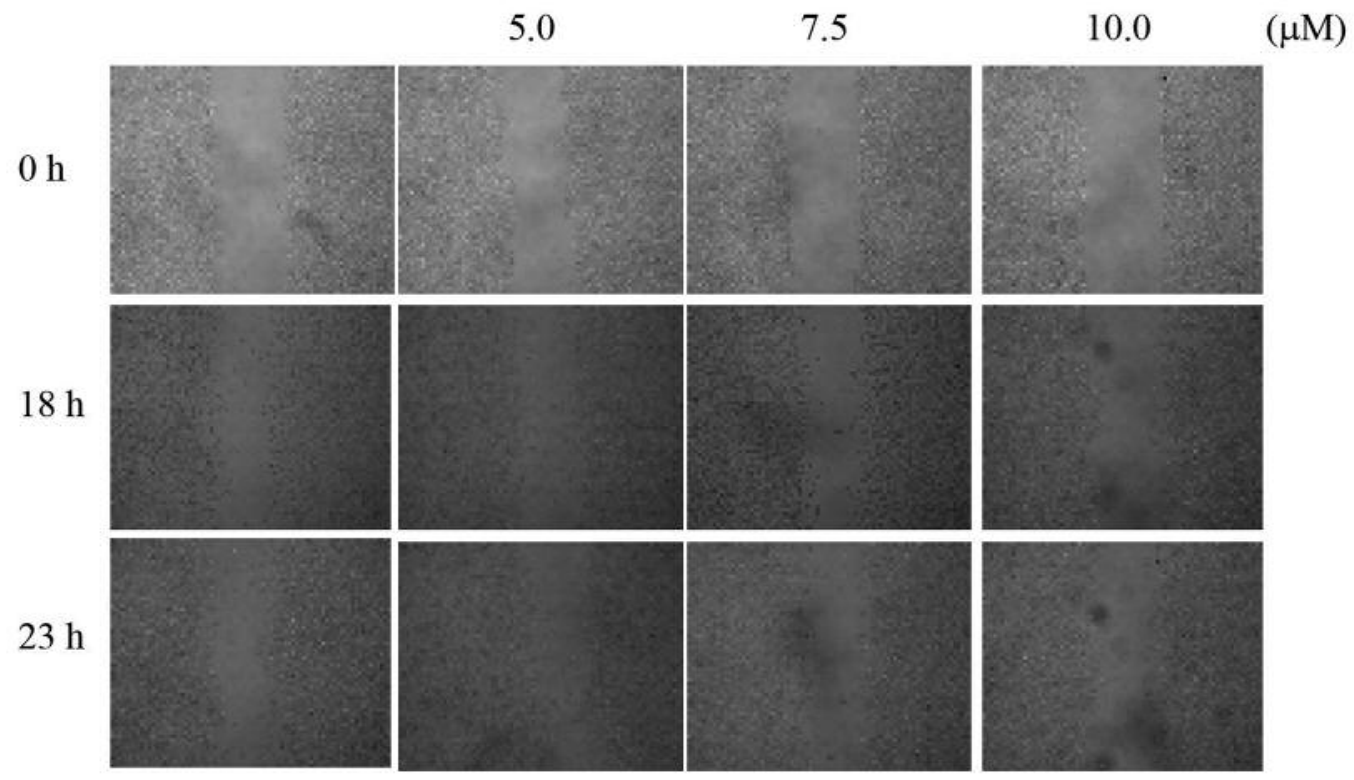

B

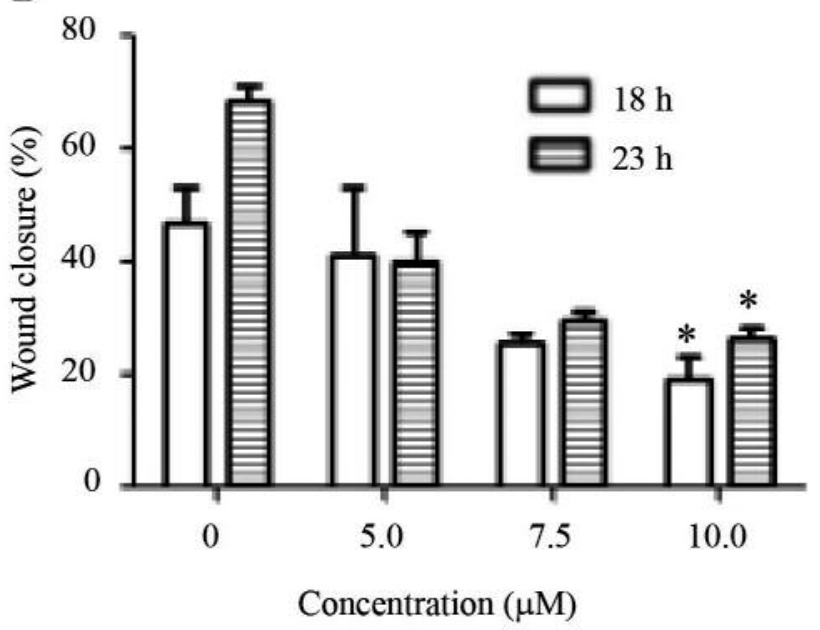

Figure 6. Compound $7 \boldsymbol{b}$ suppressed migration of LNCaP cells in vitro. A: Representative light microscopy images of wound closure (4X). Cells were grown to confluence, wounded and then incubated with different concentrations of $7 \boldsymbol{b}$. Images were captured at 0,18 and $23 \mathrm{~h}$ after wounding. Note that the wound closure was suppressed by $7 \boldsymbol{b}$ in a dose-dependent manner. B: Quantitative analysis of wound closure was performed using Image $J$ software and data are expressed as the mean \pm standard deviation. Compound $7 \boldsymbol{b}$ significantly inhibited LNCaP cell migration at $10 \mu M$ compared with the control at 18 and $23 h(* p<0.05)$.

$\mu \mathrm{M}(\mathrm{LNCaP})$. In general, the introduction of sulfate groups at $\mathrm{C}-3$ or C-16 increased cytotoxic activity against both cancer cell lines compared to the corresponding non-sulfated compounds (4 vs. 1, 9 vs. 2, 12 vs. 10, 13 vs. 11, and $15 v s$. 14). This improvement in cytotoxic activity exerted by the sulfate groups has also been observed in sulfated hydroximinosteroids $(20,28,29)$. On the other hand, the replacement of a hydroxyl group by a carbonyl group at C-3 or C-16 did not increase cytotoxicity (5 vs. 1, 16 vs. 2, and $18 v s .14)$. A similar tendency was observed for derivatives 6, 17, and 19 with one, two or three oximes groups at C-3, C-16 or C-30, compared with ketones starting corresponding (6 vs. 5, 17 vs. 16, and 19 vs. 18). Surprisingly, the presence of a C-3 amino group led to a decrease in the concentration of growth inhibition of $\mathrm{PC}-3$ and $\mathrm{LNCaP}$, with respect to lupeol, with $\mathrm{IC}_{50}$ values of 32.1 and $42.1 \mu \mathrm{M}$, respectively 
(7b vs. 1). The introduction of formyl functionality at the C30 position (compound 14) was not significant for activity. In the same way, the stereochemistry of the hydroxyl group at C-3 did not seem to be relevant for activity, at the tested concentrations. This was apparent when comparing lupeol (1) with its epimer (compound 8). Finally, neither the esterification of $\mathrm{C}-3$ and $\mathrm{C}-16$ positions with the corresponding benzoyl chlorides (compounds $\mathbf{2 0}$ and 21), nor the hydrogenation of the double bond of diol 2 (compound 22) led to an improvement in cytotoxic activity.

The identification of compounds with high cytotoxic potencies $\left(\mathrm{IC}_{50}<70 \mu \mathrm{M}\right)$ motivated further evaluation of their ability to inhibit metastatic PCa cell migration using a wound-healing assay (30). Figure 4A shows representative light microscopy wound images of PC-3 cells, while Figures $5 \mathrm{~A}$ and $6 \mathrm{~A}$ correspond to LNCaP cells. For wound-healing assays, compound concentrations with no significant drug sensitivity $\left(\mathrm{IC}_{10}\right)$ were selected. Following exposure of PC3 cells to derivative $\mathbf{1 3}$ (Figure 4A) at doses ranging from 22.5 to $27.5 \mu \mathrm{M}$, and of $\mathrm{LNCaP}$ cells to natural triterpenoid 3 (Figure 5A) and derivative $7 \mathbf{b}$ (Figure 6A) at doses ranging from 5.0 to $10.0 \mu \mathrm{M}$, wound closure was much slower and the wound was still open at 18 or $23 \mathrm{~h}$ after exposure. As wound closure reflects the migratory ability of cancer cells, these results indicate that the migration of PC-3 cells was significantly inhibited by compound $\mathbf{1 3}$ at $22.5 \mu \mathrm{M}$ at 18 or $23 \mathrm{~h}$ post-treatment $(p<0.001)$ (Figure $4 \mathrm{~B})$. In addition, compound $\mathbf{7 b}$ inhibited LNCaP cells motility at $10 \mu \mathrm{M}$ at 18 or $23 \mathrm{~h}(p<0.05)$ (Figure $6 \mathrm{~B})$, while compound 3 significantly inhibited the migration of LNCaP cells only at $23 \mathrm{~h}$ compared with the control $(p<0.05)$ at the same dose (Figure 5B).

\section{Discussion}

In summary, five new semisynthetic triterpenoids were obtained from $\mathbf{1}$ and $\mathbf{2}$, and fully characterized, together with 14 known ones, in order to evaluate their cytotoxicity against prostatic cancer cell lines. Seven derivatives showed an improvement of activity compared with the natural starting compounds. In particular, the sulfation of lupeol substantially improved its antitumor activity, which means a significant decrease in the effective dose of this triterpenoid. Our results suggest that the sulfate group might be involved in the cytotoxicity of this type of structure; further investigation into the anticancer activity of this type of triterpenoid derivative may be profitable.

The formation of new tissue, invasion and tumor cell metastasis all depend on cell motility and migration (31). Therefore, cell migration constitutes an attractive target for the development of potential antitumor compounds. Herein, results obtained for the evaluated lupanes showed that the natural tri-hydroxylated triterpenoid $\mathbf{3}$ and analogs $\mathbf{7 b}$ and $\mathbf{1 3}$ could be considered as inhibitors of cell migration after 18 and $23 \mathrm{~h}$ incubation, respectively, which might lead to a further decrease in cell invasion and consequently prevention of metastasis.

\section{Conflicts of Interest}

The Authors declare that there are no conflicts of interest in regard to this study.

\section{Authors' Contributions}

M.B.F., A.P.M. and J.C.C. were involved in planning and supervised the work; M.J.C performed the synthesis and characterization of compounds; V.P.C. and P.A.S. developed the assays on cells.

\section{Acknowledgements}

This work was financially supported by the National Research Council of Argentina (CONICET), Universidad Nacional del Sur (Argentina) and Scientific Research Commission (CIC, Argentina). M.J.C. is grateful to CONICET for her postdoctoral fellowships. P.A.S. is Professional member of CONICET. M.B.F. is a Research Member of CIC. J.C.C., V.P.C. and A.P.M. are Research Members of CONICET.

\section{References}

1 Cancer: Fact Sheet no. 297. World Health Organization, Geneva, 2015. Available at http://www.who.int/en/news-room/factsheets/detail/cancer

2 Jemal A, Bray F, Center MM, Ferlay J, Ward E and Forma D: Global cancer statistics CA. Cancer J Clin 61: 69-90, 2011. PMID: 21296855. DOI: 10.3322/caac.20107

3 Newman DJ and Giddings LA: Natural products as leads to antitumor drugs. Phytochem Rev 13: 123-137, 2014. DOI: 10.1007/s11101-013-9292-6

4 Hill RA and Connolly JD: Triterpenoids. Nat Prod Rep 30: 1028-1065, 2013. PMID: 23736383. DOI: 10.1039/c3np70032a

5 Ukiya M, Akihisa T, Tokuda H, Suzuki H, Mukainaka T, Ichiishi E, Yasukawa K, Kasahara Y and Nishino H: Constituents of Compositae plants III. Antitumor promoting effects and cytotoxic activity against human cancer cell lines of triterpene diols and triols from edible chrysanthemum flowers. Cancer Lett 177: 7-12, 2002. PMID: 11809525.

6 García A and Delgado G: Cytotoxic cis-fused bicyclic sesquiterpenoids from Jatropha neopauciflora. J Nat Prod 69: 1618-1621, 2006. PMID: 17125233. DOI: 10.1021/np060194h

7 Vela Gurovic MS, Díaz Lanza AM, Boyano Adánez MC, Estañ Omaña MC, Gañán Gómez I, Murray AP, Sancho López P: Cytotoxic effects induced by combination of heliantriol B2 and dequalinium against human leukemic cell lines. Phytother Res 25: 603-610, 2011. PMID: 20981868. DOI: $10.1002 /$ ptr.3310

8 Shanmugam MK, Nguyen AH, Kumar AP, Tan BKH and Sethi G: Targeted inhibition of tumor proliferation, survival, and metastasis by pentacyclic triterpenoids: Potential role in prevention and therapy of cancer. Cancer Lett 320: 158-170, 2012. PMID: 22406826. DOI: 10.1016/j.canlet.2012.02.037 
9 Hao J, Pei Y, Ji G, Li W, Feng S and Qiu S: Autophagy is induced by $3 \beta$-O-succinyl-lupeol (LD9-4) in A549 cells via upregulation of Beclin 1 and down-regulation mTOR pathway. Eur J Pharmacol 670: 29-38, 2011. PMID: 21939652. DOI: 10.1016/j.ejphar.2011.08.045.

$10 \mathrm{Li} \mathrm{W}$, Hao J and Xiao Y: Synthesis and in vitro antitumor activities of lupeol dicarboxylic acid monoester derivatives. Arch Pharm Res 36: 1447-1453, 2013. PMID: 23700293. DOI: 10.1007/s12272-013-0155-x

$11 \mathrm{Li} \mathrm{W}$ and Xiao Y: Synthesis and in vitro antitumour activities of lupeol derivatives. Nat Prod Res 32: 48-53, 2018. PMID: 28511560. DOI: 10.1080/14786419.2017.1329729

12 Saleem M, Kweon MH, Yun JM, Adhami VM, Khan N, Syed DN and Mukhtaret H: A novel dietary triterpene lupeol induces Fas-mediated apoptotic death of androgen-sensitive prostate cancer cells and inhibits tumor growth in a xenograft model. Cancer Res 65: 11203-11213, 2005. PMID: 16322271. DOI: 10.1158/0008-5472.CAN-05-1965

13 Prasad S, Nigam N, Kalra N and Shukla Y: Regulation of signaling pathways involved in lupeol induced inhibition of proliferation and induction of apoptosis in human prostate cancer cells. Mol Carcinog 47: 916-924, 2008. PMID: 18404669. DOI: $10.1002 / \mathrm{mc} .20442$

14 Saleem M, Murtaza I, Tarapore RS Suh Y, Adhami VM, Johnson JJ, Siddiqui IA, Khan N, Asim M, Hafeez BB, Shekhani MT, Li $\mathrm{B}$ and Mukhtar H: Lupeol inhibits proliferation of human prostate cancer cells by targeting beta-catenin signaling. Carcinog 30: 808-817, 2009. PMID: 19233958. DOI: 10.1093/ carcin/bgp044

15 Saleem M, Murtaza I, Witkowsky O, Kohl AM and Maddodi N: Lupeol triterpene, a novel diet-based microtubule targeting agent, disrupts survivin/cFLIP activation in prostate cancer cells. Biochem. Biophys Res Commun 388: 576-582, 2009. PMID: 19683515. DOI: 10.1016/j.bbrc.2009.08.060

16 Khan N, Afaq F and Mukhtar H: Cancer chemoprevention through dietary antioxidants: Progress and promise. Antioxid Redox Signal 10: 475-510, 2008. PMID: 18154485. DOI: 10.1089/ars.2007.1740.

17 Siddique HR and Saleem M: Beneficial health effects of lupeol triterpene: A review of preclinical studies. Life Sci 88: 285-293, 2011. PMID: 21118697. DOI: 10.1016/j.lfs.2010.11.020

18 Casamiquela RM, Beeskow AM, Gavirati M, Stanganelli M and Mavrek V: Usos Tradicionales de las Plantas en la Meseta Patagónica. CENPAT - CONICET - ICBG, 1-51 2002.

19 Vela Gurovic MS, Castro MJ, Richmond V, Faraoni MB, Maier MS and Murray AP: Triterpenoids with acetylcholinesterase inhibition from Chuquiraga erinacea D. Don. subsp. erinacea (Asteraceae). Planta Med 76: 607-610, 2010. PMID: 19918718. DOI: $10.1055 / \mathrm{s}-0029-1240582$

20 Richmond V, Careaga VP, Sacca P, Calvo JC and Maier MS: Synthesis and cytotoxic evaluation of four new 6E-hydroximinosteroids. Steroids 84: 7-10, 2014. PMID: 24632027. DOI: 10.10 $16 /$ j.steroids.2014.03.001
21 Amarego WLF and Chai CUU: Purification of Laboratory Chemicals. Oxford, Pergamon, 1988.

22 Castro MJ, Richmond V, Faraoni MB and Murray AP: Oxidation at C-16 enhances butyrylcholinesterase inhibition in lupane triterpenoids. Bioorg Chem 79: 301-309, 2018. PMID: 29793 143. DOI: $10.1016 /$ j.bioorg.2018.05.012

23 Castro MJ, Richmond V, Romero C, Maier MS, Estévez-Braun A, Ravelo AG, Faraoni MB and Murray AP: Preparation, anticholinesterase activity and molecular docking of new lupane derivatives. Bioorg Med Chem 22: 3341-3350, 2014. PMID: 24835788. DOI: 10.1016/j.bmc.2014.04.050

24 Yasukawa K, Yu SY, Yamanouchi S, Takido M, Akihisa T and Tamura T: Some lupane-type triterpenes inhibit tumor promotion by 12-O-tetradecanoylphorbol-13-acetate in two-stage carcinogenesis in mouse skin. Phytomed 411: 309-313, 1995. PMID: 23196020. DOI: 10.1016/S0944-7113(11)80008-5

25 Kumar S, Misra N, Raj K, Srivastava K and Puri SK: Novel class of hybrid natural products derived from lupeol as antimalarial agents. Nat Prod Res 22: 305-319, 2008. PMID: 18322846. DOI: 10.1080/14786410701766349

26 Misra N, Kumar S and Raj K: Novel class of hybrid natural products derived from lupeol/lupenone. Part (II). Indian J Chem 2: 275-283, 2011.

27 Yue PYK, Leung EPY, Mak NK and Wong RNS: A simplified method for quantifying cell migration/wound healing in 96-well plates. J Biomol Screen 15: 427-433, 2010. PMID: 20208035. DOI: $10.1177 / 1087057110361772$

28 Cui J, Wang H, Huang Y, Xin Y and Zhou A: Synthesis and cytotoxic analysis of some disodium $3 \beta, 6 \beta$-dihydroxysterol disulfates. Steroids 74: 1057-1060, 2009. PMID: 19703482. DOI: $10.1016 /$ j.steroids.2009.08.006

29 Huang Y, Cui J, Li Y, Fan L, Jiao Y and Su S: Synthesis and antiproliferative activity of some sulfated hydroximinosterols. Med Chem Res 22: 409-414, 2013. DOI: 10.1007/s00044-0120047-5

30 Rodríguez L, Wu X and Guan J: Wound-healing assay. Methods Mol Biol 294: 23-29, 2005

31 Chodniewicz D and Klemke R: Guiding cell migration through directed extension and stabilization of pseudopodia. Exp Cell Res 301: 31-37, 2004. PMID: 15501442. DOI: 10.1016/ j.yexcr.2004.08.006
Received April 10, 2019

Revised May 7, 2019

Accepted May 8, 2019 